\title{
Penerapan Algoritma Cosine Similarity untuk Deteksi Kesamaan Konten pada Sistem Informasi Penelitian dan Pengabdian Kepada Masyarakat
}

\author{
Fajar Agung Nugroho ${ }^{1}$, Fajar Septian², Dimas Abisono Pungkastyo ${ }^{3}$, Joko Riyanto ${ }^{4}$ \\ Teknik Informatika, Universitas Pamulang, Jl. Raya Puspitek No.46, Buaran, Serpong Tangerang Selatan, \\ Banten, Indonesia, 15310 \\ e-mail: dosen00670@unpam.ac..id, dosen00677@unpam.ac.id, dosen00675@unpam.ac.id, \\ jokoriyanto@unpam.ac.id
}

Submitted Date: September $30^{\text {th }}, 2020$

Revised Date: January $01^{\text {st }}, 2021$
Reviewed Date: December 30 $30^{\text {th }}, 2020$

Accepted Date: January $05^{\text {th }}, 2021$

\begin{abstract}
Research and community service activities are the obligations of a lecturer that must be carried out from part of the Tri Dharma of Higher Education in addition to teaching, where research activities should have a level of innovation in the form of development or discovery of something new, but with a large number of lecturers, this results in research activities. and community service has many similarities with previous activities. At the Lembaga Penelitian dan Pengabdian kepada Masyarakat (LPPM), Pamulang University, experiencing several problems in the management of research and community service activities, namely the absence of a system used to manage research and community service activities and data related to the track record of research and community service activities that have been carried out by 2,613 lecturers who impact on the difficulty in finding data, efficiency of storage space and more importantly is the number of similar proposals in the research itself. The research carried out aims to develop an information system that can process research and community service activities and detect similarities in content by applying the Cosine Similarity algorithm, so that it can overcome existing problems. The system development method uses a waterfall. From the results of making the system that has been carried out, it shows that the system is capable of processing activities in the field of research and community service carried out by lecturers, supporting storage, and facilitating screening of proposals for research and community service activities that will be approved.
\end{abstract}

Keywords: Research and Community Service; Cosine Similarity; Information Systems; content similarity.

\section{Abstrak}

Kegiatan penelitian dan pengabdian kepada masyarakat (PKM) adalah kewajiban seorang dosen yang harus dilaksanakan dari bagian dari tri dharma perguruan tinggi selain pengajaran, dimana kegiatan penelitian seharusnya memiliki tingkat inovasi berupa pengembangan atau penemuan sesuatu yang baru, namun dengan banyaknya jumlah dosen, mengakibatkan kegiatan penelitian dan PKM memiliki banyak persamaan dengan kegiatan sebelumnya. Pada Lembaga Penelitian dan Pengabdian Kepada Masyarakat (LPPM) Universitas Pamulang, mengalami beberapa masalah dalam pengelolaan kegiatan penelitian dan PKM yaitu belum adanya sistem yang digunakan untuk mengelola kegiatan penelitian dan PKM serta data terkait rekam jejak kegiatan penelitian dan PKM yang telah dilakukan oleh 2.613 dosen yang berdampak pada kesulitan dalam pencarian data, efesiensi ruang penyimpanan dan lebih penting adalah banyaknya kesamaan proposal dalam penelitan itu sendiri. Penelitian ini bertujuan mengembangkan sistem informasi yang dapat melakukan proses pengolahan kegiatan penelitian dan PKM, serta mendeteksi kesamaan konten dengan menerapkan algoritma Cosine Similarity, sehingga dapat mengatasi masalah-masalah yang ada. Metode pengembangan sistem menggunakan waterfall. Dari hasil pembuatan sistem yang telah dilakukan menunjukkan sistem mampu melakukan pengolahan kegiatan di bidang penelitian dan PKM yang dilakukan oleh dosen, dukungan penyimpanan, serta memudahkan penyaringan proposal kegiatan penelitian dan PKM yang akan disetujui. 
Kata Kunci: Penelitian dan Pengabdian Pada Masyarakat; Cosine Similarity; Sistem Informasi; kesamaan konten.

\section{Pendahuluan}

Kegiatan Tridharma Perguruan Tinggi merupakan hal yang tidak terlepas dan harus dilakukan oleh dosen. Sebagai seorang dosen memiliki kewajiban untuk menjalankan kegiatan tridharma yaitu pengajaran, penelitian dan pengabdian masyarakat (Hamzah, 2016). Hal ini juga berimplikasi pada penilaian prestasi dosen berdasarkan angka kredit yang diperoleh dari komponen penelitian dan pengabdian kepada masyarakat dalam syarat jabatan fungsional (Fauziah \& Retnoningsih, 2020).

Lembaga Penelitian dan Pengabdian Pada Masyarakat (LPPM) merupakan sebuah lembaga pada suatu perguruan tinggi yang bertanggung jawab dalam mengelola data kegiatan penelitian dan Pengabdian kepada Masyarakat oleh dosen. Saat ini pengolahan data administrasi penelitian dan pengabdian kepada masyarakat oleh LPPM Universitas Pamulang dilakukan dengan memanfaatkan aplikasi seperti Microsoft Excel, yang mana pencatatan data dilakukan pada banyak file yang berbeda dan sering kali file disimpan pada tempat yang berbeda. Hal ini mengakibatkan lamanya waktu yang pada saat rekapitulasi data dan penyususnan laporan (Rozaq, Hardinto, Yunida, \& Faslah, 2018). Dalam jangka panjang juga akan menimbulkan masalah keterbatasan pada media penyimpanan sehingga berdampak pada peningkatan kebutuhan sarana penyimpanan. Permasalahan lainnya juga muncul ketika dibutuhkan informasi mengenai status penelitian setiap dosen, informasi tersebut dibutuhkan untuk pengambilan keputusan strategis dan ketersediaan informasi menjadi masalah yang kritis (Joni \& Sandika, 2016). Selain itu, lemahnya proses seleksi menyebabkan banyak judul penelitian dan pengabdian kepada masyarakat yang memiliki kesamaan kurang terdeteksi sejak awal proposal diajukan. Meski tidak efektif, mendeteksi plagiat dapat dilakukan dengan cara manual yang mana harus memeriksa artikel dibandingkan dengan ribuan artikel lainnya, serta harus melihat gaya penulisannya (Pratama, Faisal, \& Hanani, 2019).

Berdasarkan pemasalahan di atas, maka dilakukan upaya untuk mengembangkan sistem informasi penelitian dan PKM yang dapat dimanfaatkan oleh LPPM Universitas Pamulang sebagai sumber informasi yang menyajikan data penelitian dan pengabdian kepada masyarakat.
Sistem ini juga dapat menjadi wadah untuk digitalisasi hasil penelitian dan pengabdian yang berupa dokumen elektronik. Selain itu, pada sistem ini juga akan menerapkan algoritma cosine similarity yang dapat mendeteksi kesamaan konten proposal penelitian dan pengabdian kepada masyarakat yang diajukan.

Cosine similarity adalah sebuah algoritma yang dapat digunakan sebagai metode dalam menghitung tingkat kesamaan (similarity) antar dokumen. Pada dasarnya proses penghitungannya menggunakan ukuran kesamaan ruang vektor (vector space similarity measure). Algoritma cosine similarity ini menggunakan kata kunci pada sebuah dokumen sebagai ukuran untuk menghitung tingkat kesamaan antar dokumen yang dinyatakan dalam bentuk vektor (Wahyuni, Prastiyanto, \& Supraptono, 2017).

Hasil penelitian berupa aplikasi yang memudahkan LPPM Universitas Pamulang dalam mengelola data kegiatan penelitian dan pengabdian kepada masyarakat, selain itu aplikasi juga dilengkapi dengan pengecekan substansi proposal untuk mendeteksi tingkat kemiripan dengan menghitung nilai cos dari sudut diantara dua vektor (Cosine Similarity), sehingga substansi proposal akan lebih bervariatif.

\section{Sistem Informasi}

Sistem merupakan komponen-komponen yang saling berhubung yang memiliki tujuan sama untuk kebutuhan organisasi (Romney \& Steinbart, 2015). Informasi adalah kumpulan dari yang telah diolah sehingga bermanfaat bagi penggunanya (Romney \& Steinbart, 2015).

Sistem informasi adalah kumpulan elemen-elemen yang terintegritasi, saling terhubung dan melengkapi untuk mencapai tujuan yang diharapkan dengan output yang baik guna memecahkan masalah dan pengambilan keputusan (Krismiaji, 2015).

\section{Cosine Similarity}

Consine Similarity adalah algoritma yang dapat digunakan untuk melakukan perhitungan kesamaan dari sebuah dokumen. Untuk notasi himpunan pada consine similarity digunakan rumus (Wahyuni, Prastiyanto, \& Supraptono, 2017): 
$\operatorname{Cos} \operatorname{Sim} \alpha=\frac{A \cdot B}{|A \| B|}=\frac{\sum_{i=1}^{n} A i X B i}{\sqrt{\sum_{i=1}^{n}(B i) \mathbf{2}} X \sqrt{\sum_{i=1}^{n}(A i) \mathbf{2}}} \cdot$

Di mana :

$\mathrm{A}=$ Vektor A, yang akan dibandingkan kemiripannya

$\mathrm{B}=$ Vektor B, yang akan dibandingkan kemiripannya

vektor B

A.B $=$ dot product antara vektor $\mathrm{A}$ dan

A $\quad=$ panjang vektor $\mathrm{A}$

$|\mathrm{B}| \quad$ = panjang vektor $\mathrm{B}$

$|\mathrm{B}|$

$|\mathrm{A}||\mathrm{B}|=$ cross product antara $|\mathrm{A}|$ dan

Langkah-langkah perhitungan manual algoritma Cosine Similarity antara lain:

a) Langkah pertama terlebih dahulu kita tentukan query dari jawaban (A) dan query dari key jawaban (B) dan kemudian gabungan dari kedua query tersebut (Queries).

b)Dari ketiga query yang ada selanjutnya dilakukan penghapusan stoplist atau tanda baca yang tidak mempengaruhi penilaian, seperti tanda titik(.), tanda koma(,), tanda seru(!), dan tanda baca lainnya.

c) Menghilangkan stopword (kata-kata umum) yang lazim digunakan pada ketiga query tersebut kata-kata umum dalam suatu query, seperti "di", "dan", "tetapi", "jika", "namun", dan kata hubung lainnya.

d)Menghitung nilai term frequency dari query jawaban dan query key jawaban terhadap queries.

e) Hitung nilai banyaknya file $(\mathrm{N})$ atau document frequency (n) yang memiliki suatu term untuk tiap term dalam queries.

f) Menghitung nilai inverse document frequency dengan rumus $\log (\mathrm{N} / \mathrm{n})+1$.

\section{Metode Penelitian}

Pada metode penelitian dibagi menjadi 2 tahapan, yaitu:

a. Metode Pengumpulan data

Pengumpulan data diperlukan untuk menunjang proses penelitian ini, adapun metode yang digunakan dalam pengumpulan data antara lain studi pustaka / literatur, wawancara, dan observasi.

b. Metode Pengembangan Sistem

Metode pengembangan sistem yang digunakan adalah waterfall, yang digunakan sebagai alur untuk membangun sebuah perangkat lunak dimulai dari tahap analisa kebutuhan sistem, tahap desain atau perancangan, tahap implementasi, tahap pengujian dan yang terakhir adalah tahap pemeliharaan. Setelah semua langkah berhasil dilakukan maka terbentuklah sebuah sistem yang sesuai dengan kebutuhan (Rosa \& Shalahuddin, 2015).

\section{Hasil dan Pembahasan}

Untuk merancang sebuah sistem yang baik langkah pertama adalah harus mengumpulkan data dan informasi tentang sistem yang saat ini berjalan, sebagai langkah awal dengan cara menganalisa sistem yang ada dan dari analisa tersebut dapat diketahui kekurangan sistem yang akan disempurnakan pada sistem yang dirancang. Dari hasil analisis sistem berjalan tersebut kita juga dapat mengetahui kebutuhan-kebutuhan informasi yang akan dibuat.

Untuk pengusulan penelitian dan pengabdian masyarakat selama ini dimulai dengan menggunakan template yang ditentukan oleh LPPM Universitas Pamulang. Tahap berikutnya yaitu mencetak usulan tersebut dan mengajukan langsung ke LPPM melalui operator LPPM. Persetujuan didapatkan setelah usulan direview oleh reviewer dan Ketua LPPM. Proses berikutnya adalah penerbitan surat kontrak, surat tugas, dan surat permohonan ke instansi yang dituju. Selama periode penelitian dan pengabdian masyarakat, para pengusul melakukan pelaporan kemajuan mengenai hal-hal yang telah dicapai. Setelah pelaksanaan penelitian dan pengabdian masyarakat selesai, maka dilakukan pembuatan laporan akhir oleh para pengusul. Proses akhir adalah review laporan akhir dan pengesahan laporan akhir oleh Ketua LPPM. Adapun skema penelitian dan pengabdian dapat dilihat pada gambar berikut ini: 


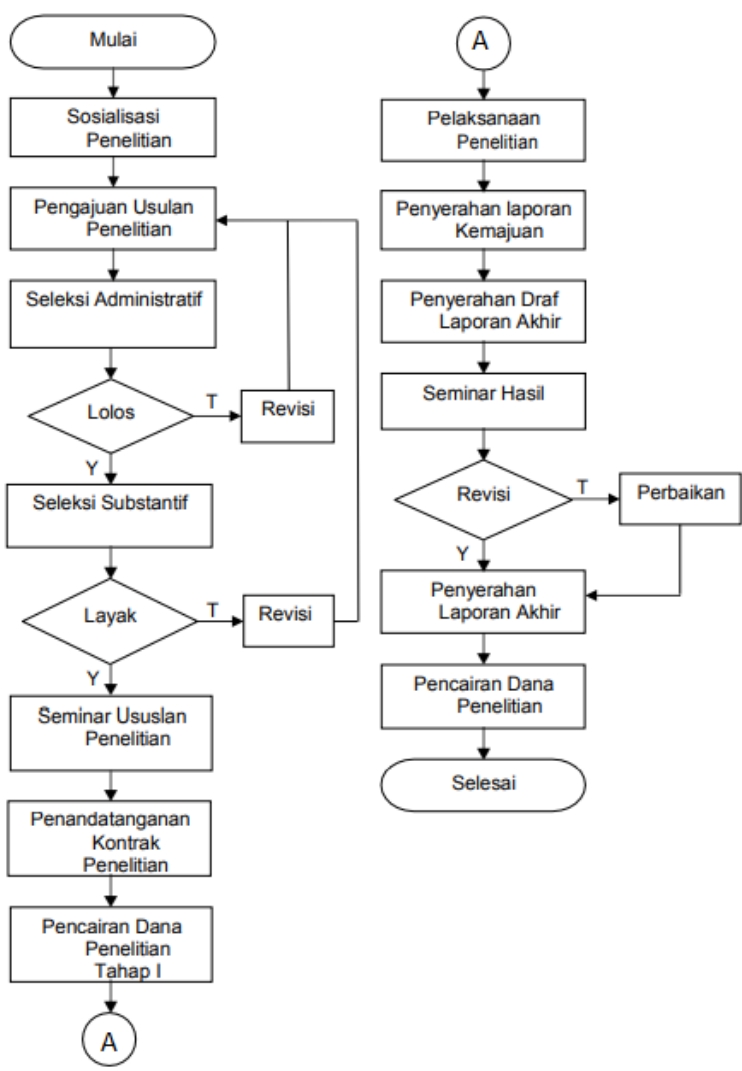

Gambar 1. Skema Penelitian

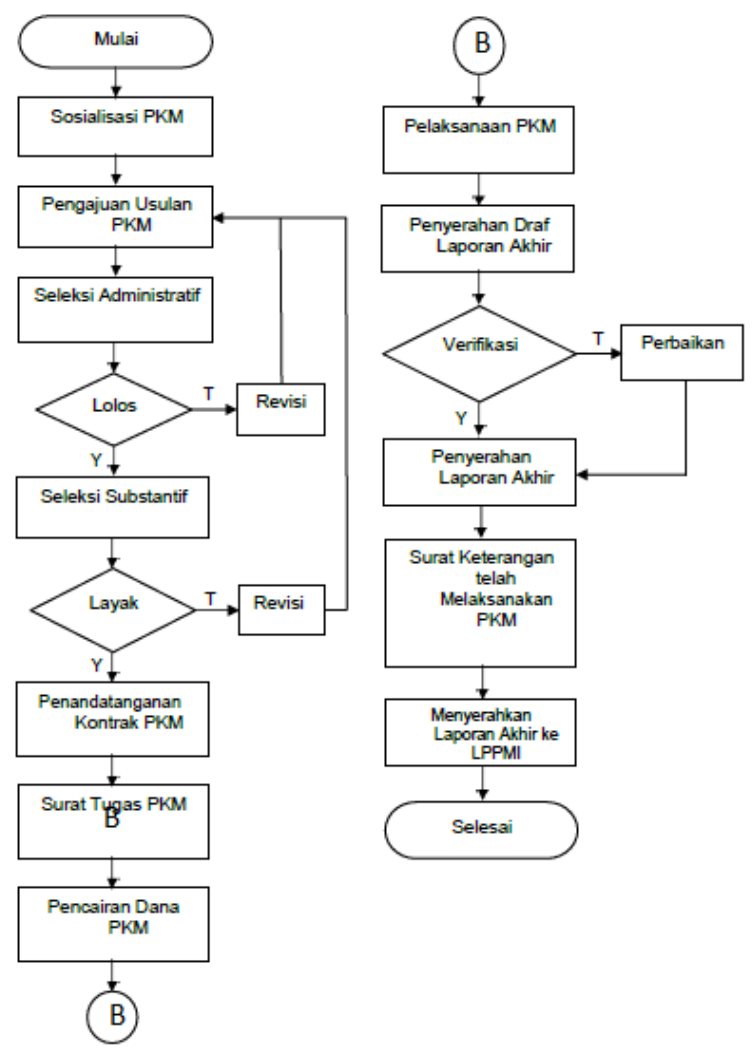

Gambar 2. Skema Pengabdian Kepada Masyarakat
Dalam beberapa tahapan administrasi di atas, sering kali mengalami hambatan dalam hal efisiensi waktu. Hal ini perlu dilakukan perbaikan untuk meningkatkan kinerja LPPM dan meminimalkan waktu proses setiap tahapan yang telah disebutkan di atas.

Untuk memperbaiki proses pengusulan sampai pelaporan akhir kegiatan penelitian maupun pengabdian kepada masyarakat, maka diusulkan sebuah sistem baru yang dapat memfasilitasi para pengusul untuk mengajukan penelitian dan PKM di tingkat lokal Universitas Pamulang. Sistem yang akan diusulkan merupakan sistem yang dapat digunakan secara multiuser. Dalam sistem ini akan ada 4 pengguna, yaitu dosen sebagai pengusul, dosen sebagai reviewer, Ketua LPPM dan admin LPPM. Adapun rinciannya sebagai berikut:

a. Fitur Dosen Pengusul

Untuk dosen sebagai pengusul disediakan beberapa fitur seperti pengajuan usulan baru penelitian, daftar usulan penelitian yang telah/sedang dilaksanakan, pengajuan usulan pengabdian kepada masyarakat, daftar usulan pengabdian yang telah/sedang dilaksanakan, tahap persiapan penelitian dan pengabdian (cetak surat tugas, surat kontrak, surat permohonan penelitian), laporan kemajuan penelitian maupun pengabdian, dan pelaporan akhir kegiatan penelitian dan pengabdian. Pada fitur ini seorang dosen dapat menjadi ketua pengusul maupun anggota pengusul, yang membedakan hanya pada persetujuan menjadi anggota saja.

b. Fitur Dosen Reviewer

Untuk dosen reviewer fitur yang disediakan tidak jauh berbeda dengan dosen pengusul. Namun, ada fitur tambahan berupa review usulan penelitian dan pengabdian. Pada fitur ini reviewer memberikan masukan dan penilaian terhadap usulan penelitian maupun pengabdian yang dilakukan dosen pengusul yang ditujukan kepadanya.

c. Fitur Admin LPPM

Pada fitur admin LPPM terdapat layanan untuk monitoring penelitian, monitoring pengabdian, menambah reviewer, melakukan pengaturan tanggal penentuan untuk pembukaan maupun penutupan usulan penelitian dan pengabdian, laporan kemajuan dan laporan akhir, dan menambahkan user.

d. Fitur Ketua LPPM

Pada fitur ketua LPPM tidak berbeda jauh dengan fitur yang terdapat pada admin LPPM. Hanya saja terdapat fitur monitoring penelitian 
telah dinilai, monitoring pengabdian telah dinilai, persetujuan substansi penelitian, persetujuan substansi pengabdian kepada masyarakat.
Gambaran dari fitur-fitur pengguna dapat dilihat pada use case berikut:

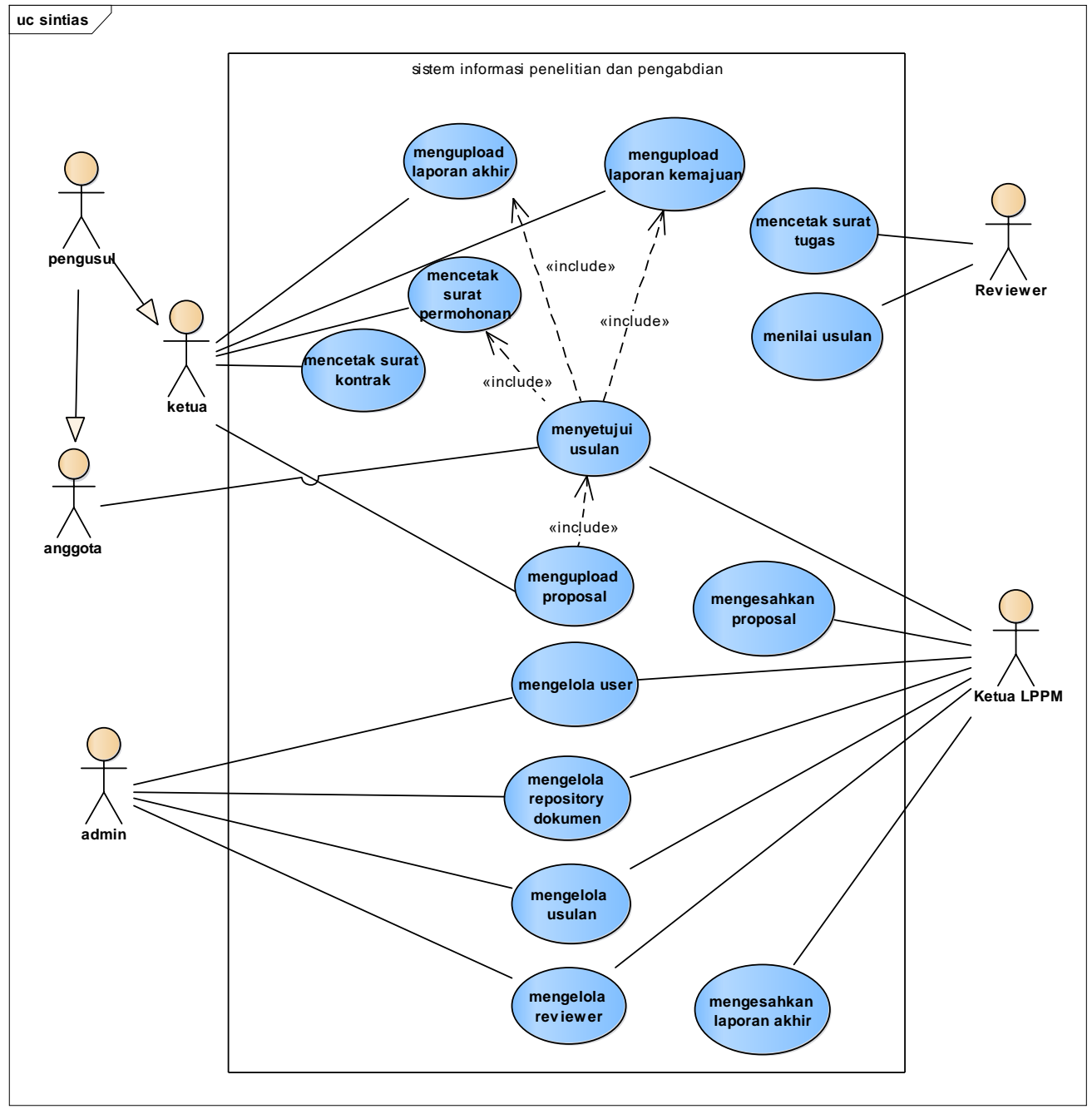

Gambar 3. Fitur Sistem Usulan

\section{Skenario Perhitungan Kemiripan Dokumen dengan Cosine Similarity}

Dalam perhitungan tingkat kemiripan dokumen, dilakukan perhitungan menggunakan Cosine Similarity pada dokumen abstrak dan judul. Dengan keadaan dimana admin telah memiliki daftar kata pada repository yang akan diukur kemiripannya. Pada penelitian ini, digunakan 5 dokumen usulan yang telah terdapat pada repository dan 1 data uji yang akan dicek tingkat kemiripannya.

Langkah pertama lakukan preprocessing terhadap semua $(n=6)$ dokumen yang akan diukur similaritasnya, yaitu Q, D1, D2, D3, D4, D5. Langkah berikutnya, lakukan tokenisasi, stop words removal dan stemming. Misalnya query yang dicari yaitu Q yang merupakan kinerja guru dalam membangun sumber daya manusia. Kemudian dijabarkan judul dan abstrak pada dokumen yang ingin dicari kemiripannya. Dari setiap daftar kalimat data uji dilakukan stemming yaitu dengan melakukan pendekatan terhadap struktur morfologi yang ada dalam bahasa yang sesuai dengan aturan imbuhan untuk dapat digunakan mengekstrak kata dasar (Zulfikar, 2017).

Langkah selanjutnya, tentukan bobot untuk setiap term dari 6 dokumen yang ada Kemudian hitung nilai kemiripan vektor (dokumen) query $\mathrm{Q}$ dari setiap dokumen. Untuk mengecek kemiripan antar dokumen yang satu dengan lainnya dapat menggunakan 
cosine similarity. Langkahnya dengan menghitung hasil perkalian skalar antara Q dan 5 dokumen lain. Hasilnya perkalian dari setiap dokumen dengan Q dijumlahkan.

Langkah selanjutnya, menerapkan rumus cosine similarity. Hitung kemiripan Q dengan D1, D2 dan seterusnya sampai dengan D5:

$\operatorname{Cos}(\mathrm{Q}, \mathrm{D} 1)=0 /(0,398 * 3,001)=0$

$\operatorname{Cos}(\mathrm{Q}, \mathrm{D} 2)=0,273 /(0,398 * 4,706)=$ 0,145

$\operatorname{Cos} \quad(\mathrm{Q}$,

D3)

$0,409 /(0,398 * 3,744)=0,274$

$\operatorname{Cos} \quad(\mathrm{Q}$,

D4) =

$0,188 /(0,398 * 3,423)=0,137$

Cos $\quad(\mathrm{Q}$,

D5) =

$0,330 /(0,398 * 2,718)=0,304$

Perhitungan hasil kemiripan dokumen diperlihatkan pada tabel berikut:

Tabel 1. Perhitungan Hasil Kemiripan Dokumen

\begin{tabular}{|l|l|l|l|l|}
\hline D1 & D2 & D3 & D4 & D5 \\
\hline 0 & 0,145 & 0,27 & 0,137 & 0,304 \\
\hline
\end{tabular}

Dari hasil perhitungan kemiripan diperoleh:

Tabel 2. Hasil Pengurutan Dokumen

\begin{tabular}{|l|l|l|l|l|}
\hline 1 & 2 & 3 & 4 & 5 \\
\hline D5 & D3 & D2 & D4 & D1 \\
\hline
\end{tabular}

\section{Implementasi Antarmuka}

Adapun desain tampilan untuk sistem penelitian dan pengabdian masyarakat sebagai berikut:

a. Halaman Login

Halaman ini digunakan untuk membatasi akses user yang akan menggunakan aplikasi.

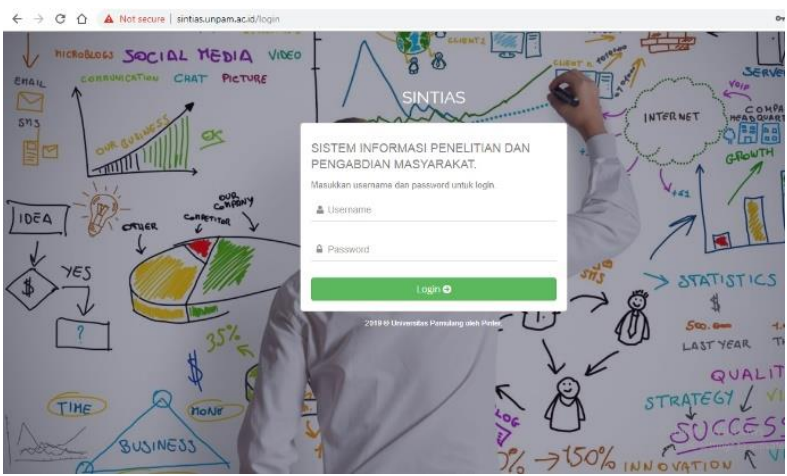

Gambar 4. Halaman Login

b. Halaman Substansi Usulan

Halaman ini digunakan untuk memasukkan substansi usulan, tahun pengajuan, tahun pelaksanaan, rencana anggaran belanja, luaran yang dijanjikan.

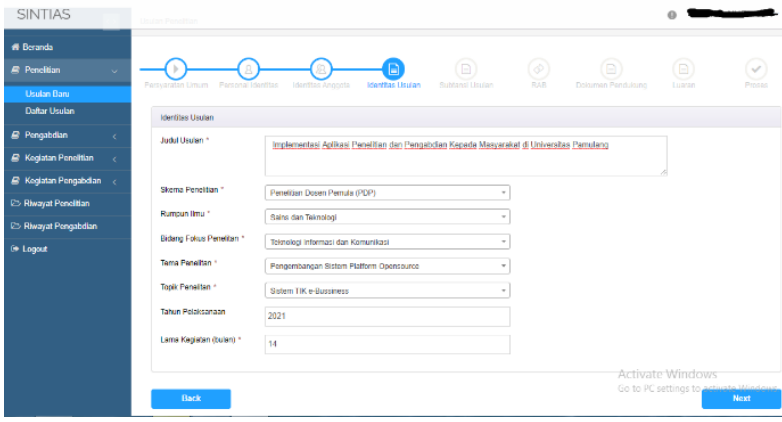

Gambar 5. Halaman Substansi Usulan

c. Halaman Dashboard

Halaman ini terdapat beberapa diagram yang menampilkan persentase pencapaian penelitian dan pengabdian masyarakat di seluruh program studi.

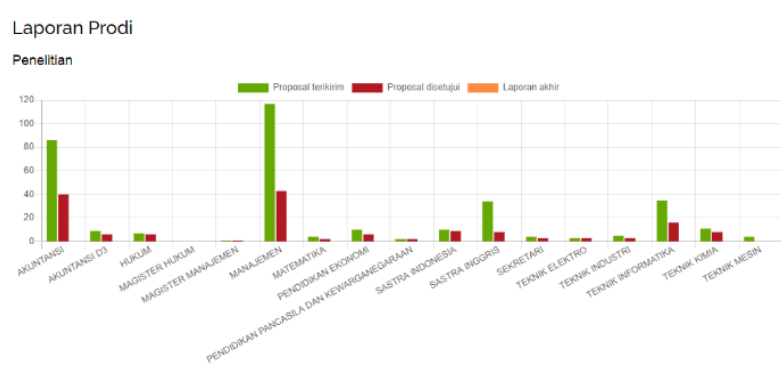

Gambar 6. Halaman Dashboard

\section{d. Halaman Daftar Usulan}

Halaman ini berfungsi untuk menampilkan semua daftar usulan penelitian. Ditambah fungsi penyaringan data untuk membantu pencarian.

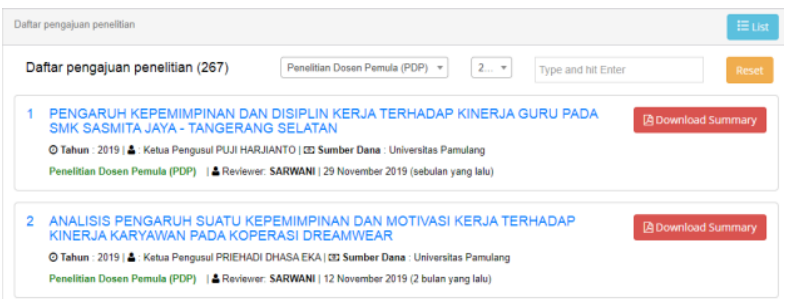

Gambar 7. Halaman Daftar Usulan

e. Halaman Tambah Reviewer

Halaman ini berfungsi menambahkan dosen ke daftar reviewer sesuai bidang keahlian dosen tersebut. 


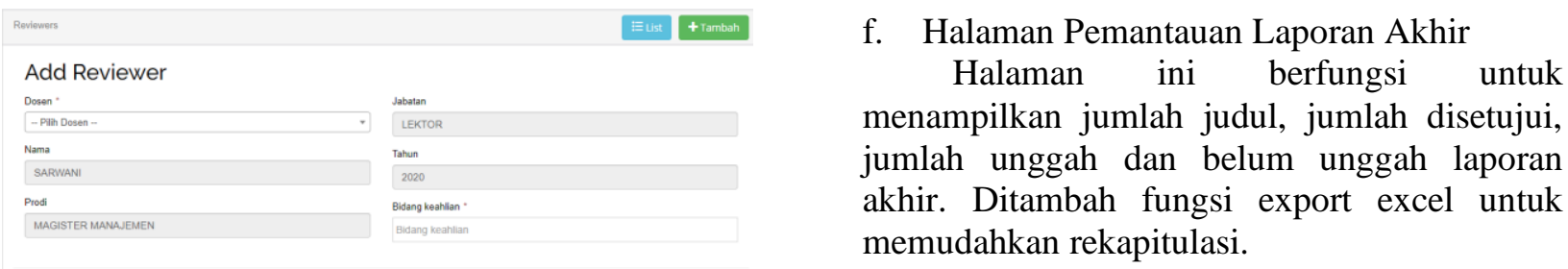

Gambar 8. Halaman Tambah Reviewer

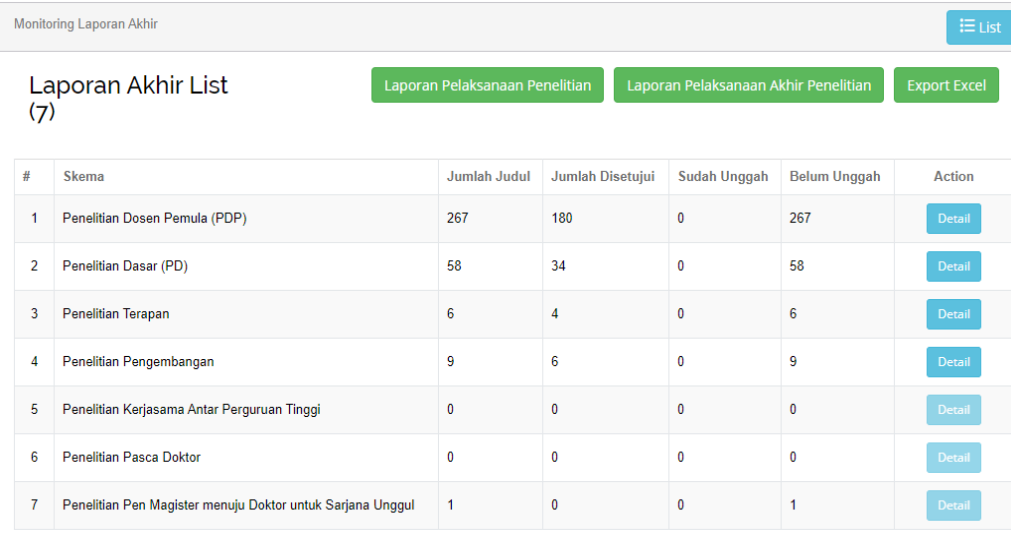

Gambar 9. Halaman Monitoring Laporan Akhir

g. Halaman Penilaian Reviewer

Halaman ini berfungsi untuk memasukkan penilaian atas usulan yang diajukan oleh pengusul. Kemudian perolehan nilai akhir berdasarkan perkalian bobot dan skor.
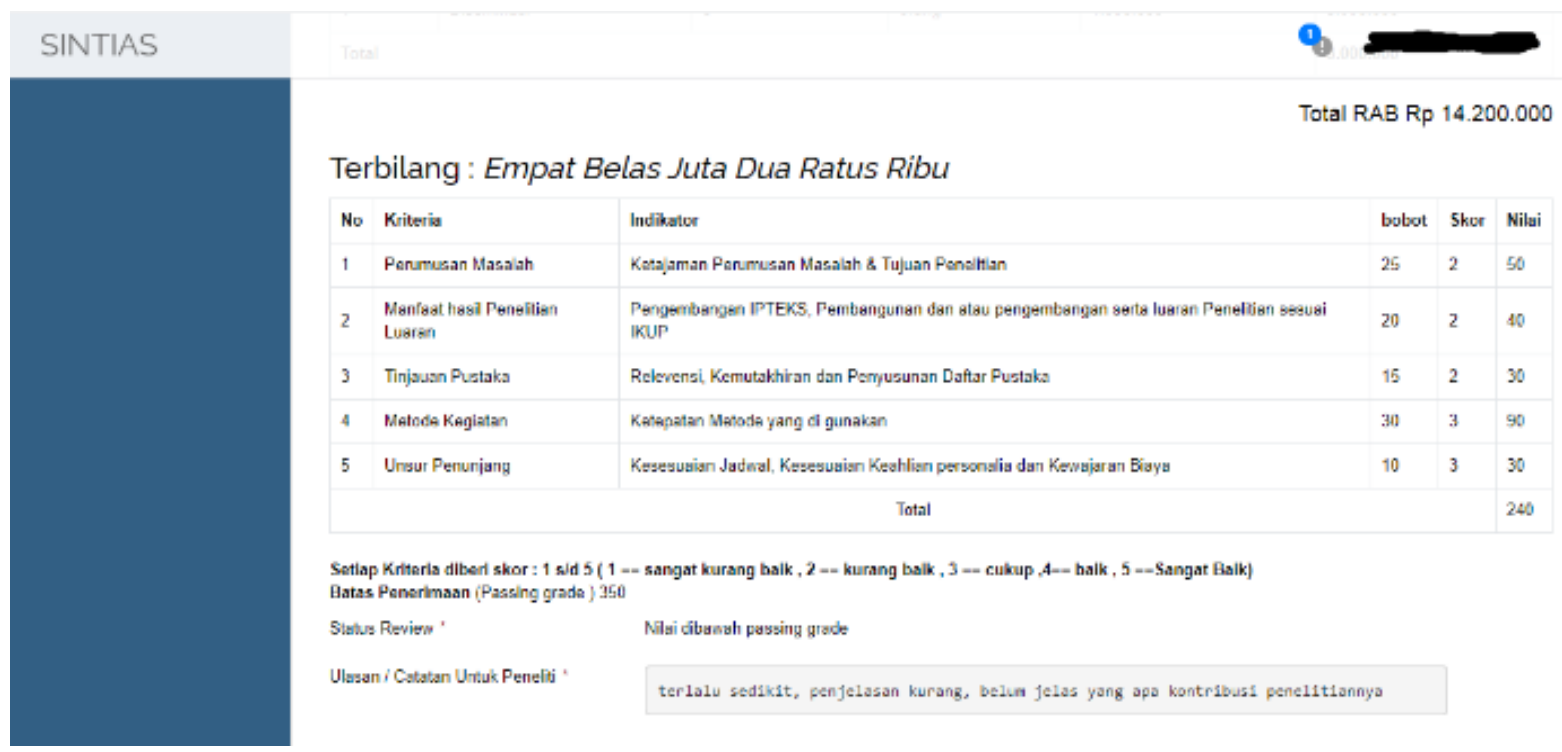

Gambar 10. Halaman Penilaian Reviewer

\section{Kesimpulan}

Setelah sistem informasi penelitian dan PKM ini melewati semua tahapan dimulai dari analisa, perancangan, pembuatan sampai pengujian, dapat ditarik kesimpulan sebagai berikut:

a. Sistem dapat memudahkan user pengusul dalam mengajukan proposal penelitian dan PKM serta proses pelaporan. 
b. Sistem dapat memudahkan LPPM dalam mengelola seluruh kegiatan penelitian dan PKM yang dilakukan oleh dosen.

c. Sistem dapat menampilkan persentase tingkat kesamaan dokumen dari judul dan abstrak.

d. Sistem ini dapat membuktikan pelaksanaan kegiatan penelitian dan pengabdian kepada masyarakat lebih sistematis karena dukungan media penyimpanan yang lebih baik serta prosedur yang dilakukan secara komputerisasi lebih cepat dalam menyajikan data penelitian dan pengabdian masyarakat secara akurat. Dengan diterapkanya algoritma cosine similarity dapat mempermudah LPPM dalam proses seleksi proposal.

\section{Daftar Pustaka}

Fauziah, N. F., \& Retnoningsih, E. (2020). Sistem Informasi Penelitian dan Pengabdian kepada Masyarakat Berbasis Web. Information Management for Educators and Professionals, 4(2), 183-192.

Hamzah. (2016). Sistem Informasi Kegiatan Penelitian dan Pengabdian Kepada Masyarakat Universitas Respati Yogyakarta. JURNAL TEKNOSI Vol. 2, No. 2, Agustus 2016, 17-26.

Joni, I. D., \& Sandika, I. K. (2016). Sistem Informasi Manajemen Sebagai Alat Pengelolaan Penelitian Dosen. LONTAR KOMPUTER VOL. 7, NO. 1, APRIL 2016, 51-60.
Krismiaji. (2015). Sistem Informasi Akuntansi Edisi Keempat. Yogyakarta: UPP STIM YKPN.

Pratama, R. P., Faisal, M., \& Hanani, A. (2019). Deteksi Plagiarisme pada Artikel Jurnal Menggunakan Metode Cosine Similarity. SMARTICS Journal, Vol.5 No. 1 2019, 22-26.

Romney, M. B., \& Steinbart, P. J. (2015). Sistem Informasi Akuntansi Edisi 13. Jakarta: Salemba Empat.

Rosa, A., \& Shalahuddin, M. (2015). Rekayasa Perangkat Lunak Terstruktur dan Berorientasi Objek. Bandung: Informatika.

Rozaq, A., Hardinto, R. K., Yunida, R., \& Faslah, R. (2018). Sistem Informasi Penelitian dan Pengabdian Masyarakat Guna Meningkatkan Kinerja P3M Politeknik Negeri Banjarmasin. Jurnal Sains Terapan Teknologi Informasi, 10(2), 36-41.

Wahyuni, R. T., Prastiyanto, D., \& Supraptono, E. (2017). Penerapan Algoritma Cosine Similarity dan Pembobotan TF-IDF pada Sistem Klasifikasi Dokumen Skripsi. Jurnal Teknik Elektro Vol. 9 No. 1, 18-23.

Zulfikar, A. F. (2017). Pengembangan Algoritma Stemming Bahasa Indonesia dengan Pendekatan Dictionary Base Stemming untuk Menentukan Kata Dasar dari Kata yang Berimbuhan. Jurnal Informatika Universitas Pamulang, 2(3), 143-146. 